Vol. 15 (2006): 414-422.

\title{
Quality and shelf life of packaged fresh sliced mushrooms stored at two different temperatures
}

\author{
Elena González-Fandos \\ Departamento de Agricultura y Alimentación, Universidad de la Rioja, C/ Madre de Dios 51, 26006 Logroño, \\ Spain,e-mail: elena.gonzalez@daa.unirioja.es \\ Ana Simón Jiménez and Vanesa Tobar Pardo \\ Centro de Investigación y Desarrollo Agrario, Gobierno de la Rioja, Crta. Logroño-Mendavia km 87, \\ 26071 Logroño, Spain
}

\begin{abstract}
The sensory and microbiological quality of sliced mushrooms (Agaricus bisporus L.) packaged in films of perforated and non-perforated PVC and stored at 3 and $9^{\circ} \mathrm{C}$, was studied. The carbon dioxide and oxygen content inside the packages, colour, weight loss, sensory attributes, mesophiles, Pseudomonas, Enterobacteriaceae, aerobic and anaerobic spore formers were determined. The atmosphere generated with the perforated PVC film was similar to that of air atmosphere at 3 or $9^{\circ} \mathrm{C}$. The non-perforated PVC film generated inside the packages $\mathrm{CO}_{2}: \mathrm{O}_{2}$ concentrations of $3.4 \%: 8.1 \%$ at $3^{\circ} \mathrm{C}$ and $\mathrm{CO}_{2}: \mathrm{O}_{2}$ concentrations of $4.5 \%$ : $0.15 \%$ at $9^{\circ} \mathrm{C}$. Browning of mushrooms was lower at 3 than at $9^{\circ} \mathrm{C}$. The quality of sliced mushrooms packaged in perforated $\mathrm{PVC}$ and stored at $3^{\circ} \mathrm{C}$ was adequate after 9 days. However, at $9^{\circ} \mathrm{C}$, the slice deformation and brown blotches incidence were severe after 9 days. The atmosphere generated with non-perforated PVC inhibited aerobic microorganism growth compared to mushrooms packaged in perforated $\mathrm{PVC}$. At $3^{\circ} \mathrm{C}$, the shelf life of mushrooms packaged in non perforated PVC was around 13 days. However, the extremely low $\mathrm{O}_{2}$ atmospheres generated at $9^{\circ} \mathrm{C}$ was accompanied by off-odours and growth of anaerobic spore formers, although the appearance of sliced mushrooms was acceptable.
\end{abstract}

Key-words: modified atmospheres, minimal processing, sensorial and microbiological quality, sliced mushrooms

\section{Introduction}

Production of sliced mushrooms is growing because of increased consumer demand for fresh 'ready-to-use' products. In spite of their increasing demand, there is little information available on their quality, shelf life or safety (Brennan and Gormley 1998, Brennan et al. 2000), most research focusing on whole mushrooms.

Slicing enhances spoilage problems as it prompts an increase in the respiration rate and cre- 
Vol. 15 (2006): 414-422.

ates a larger surface area susceptible to dehydratation, browning and microbial growth (Brennan and Gormley 1998).

Sliced mushrooms are usually marketed in trays overwrapped with plastic films that reduce dehydration and stored under refrigeration temperatures. A modified atmosphere is created inside the package, depending on the respiratory activity of the mushrooms, the permeability of the film to gases, the amount of product, the proportion between this amount and the film surface area and the storage temperature (Kader 1986, López-Briones et al. 1993). The modified passive atmospheres produced can exert diverse effects on the sensory and microbiological quality of mushrooms.

Atmospheres containing $2.5 \% \mathrm{CO}_{2}$ and $10 \%$ $\mathrm{O}_{2}$ are considered as adequate for whole mushrooms (López-Briones et al. 1992, Tano et al. 1999). However, atmospheres above $5 \% \mathrm{CO}_{2}$ are considered as phytotoxic (López-Briones et al. 1992). On other hand, $\mathrm{O}_{2}$ levels below $2 \%$ are related to anaerobic respiration in mushrooms (Burton et al. 1987, Beit-Halachmy and Mannheim 1992) with the consequent accumulation of ethanol and acetaldehyde and the production of offodours (Tano et al. 1999), besides the risk of growth of anaerobic pathogens (Sugiyama and Yang 1975). Mushroom development is inhibited by $\mathrm{CO}_{2}$ concentrations upper than $5 \%$ (Murr and Morris 1975, López-Briones et al. 1992) and $\mathrm{O}_{2}$ levels lower than 5\% (Roy et al. 1995).

The moisture and modified atmospheres created in the packages also influence microbial growth. Burton et al. (1987) reported an enhancement in the disease symptoms causes by Pseudomonas tolaasii in whole mushrooms when $\mathrm{O}_{2}$ concentration increased and $\mathrm{CO}_{2}$ concentration decreased. Moreover, López-Briones et al. (1992) observed a reduction in mesophiles under anoxic conditions and a slight effect of controlled atmospheres on P. fluorescens.

Simón et al. (2005) evaluated the effect of four different packaging films on the quality of sliced mushrooms stored at $4^{\circ} \mathrm{C}$. These authors used perforated and non-perforated polyvinylchloride (PVC) and P-Plus films. PVC films are the most common ones, while P-Plus can be an alternative to PVC films, due to the environmental problems of the latter. However, nowadays PVC films are widely used in mushrooms packaging, probably due to their low cost. The non-perforated PVC and the P-Plus 240 generated $\mathrm{CO}_{2}$ levels of $2.5 \%$ and $\mathrm{O}_{2}$ levels of $10-20 \%$, these atmospheres reduced the microbial counts when compared to the atmosphere generated with the perforated PVC which was similar to the composition of air atmosphere. The P-Plus 30 generated a highly-modified atmosphere with a $\mathrm{CO}_{2}$ concentration of around $15 \%$ and anoxia $\left(<0.1 \%\right.$ of $\left.\mathrm{O}_{2}\right)$, this atmosphere was related to off-odours and anaerobic spore formers detection.

Refrigeration temperature is the main factor responsible for maintaining the quality of fresh mushrooms (Beit-Halachmy and Mannhein 1992, Simón 2001) because it determines the speed of all metabolic processes and microbial growth. It also influences the atmosphere generated inside the packages because of its effect on the respiration rate of the product and the permeability of the film to gases (Zagory and Kader 1988). The temperature recommended to maintain mushroom quality is $0-1.5^{\circ} \mathrm{C}$ (Suslow and Cantwell 1999). However, in the marketing stage, temperatures usually ranges from $3^{\circ} \mathrm{C}$ to $10^{\circ} \mathrm{C}$ (López-Briones et al. 1992).

The aim of this study was to study the influence of storage temperature, within the standard commercial temperature range $\left(3\right.$ and $\left.9^{\circ} \mathrm{C}\right)$, on the atmospheres generated in packages of sliced mushrooms, overwrapped with films of perforated and nonperforated PVC, as well as on the sensory and microbiological quality and shelf life of this product.

\section{Material and methods}

Mushrooms (Agaricus bisporus L.) of the Amicel $\mathrm{K} 4$ strain and from the second flush were supplied by a local producer (La Rioja, Spain). The mushrooms were carefully collected; only healthy fruits in the stage 1 or 2 according to the Guthrie's scale cited by Roy et al. (1995), with a pilei diameter of 
González-Fandos, E. et al. Packaged fresh sliced mushrooms

4-5 cm, were selected. After picking, mushrooms were transferred within half an hour to the laboratory, where they were cooled at $3^{\circ} \mathrm{C}$ and stored at $3^{\circ} \mathrm{C}$ for $24 \mathrm{~h}$ in order to reduce the respiration rate (Nichols 1985).

Stipes were trimmed at $1 \mathrm{~cm}$ and then sliced (4 $\mathrm{mm}$ thickness) using a food processor (Börner, Niederkail, Germany). The slices were placed in polystyrene trays (200g per tray) measuring $22.5 \times$ $13.5 \times 3 \mathrm{~cm}$. The trays were overwrapped with two different PVC films normally used in the market: Film A was a perforated PVC film of $12 \mu \mathrm{m}$ thickness; Film B was a non-perforated PVC film of 12 $\mu \mathrm{m}$ thickness with an $\mathrm{O}_{2}$ permeability of $25000 \mathrm{ml}$ $\mathrm{m}^{-2}$ day $^{-1} \mathrm{~atm}^{-1}$ at $25^{\circ} \mathrm{C}$ and a water vapor transmission rate of $200 \mathrm{~g} \mathrm{~m}^{-2} \mathrm{day}^{-1}$ at $25^{\circ} \mathrm{C}$ according to the data provided by the manufacturer. Both films were provided by Borden España S.A (Alicante, Spain). The trays overwrapped in each type of film were divided into two batches that were stored in cold chambers at $3^{\circ} \mathrm{C}$ or $9^{\circ} \mathrm{C}$, with a programmed relative humidity of $70 \%$ for up to 13 days.

Samples were taken on days 0, 6, 9 and 13 of storage. The following variables were determined on two trays by treatment and day: gas composition $\left(\mathrm{CO}_{2}\right.$ and $\left.\mathrm{O}_{2}\right)$ inside the package, colour, sensorial quality, weight loss and microbiological quality (mesophiles, Pseudomonas, Enterobacteriaceae, aerobic and anaerobic spore formers) of the mushrooms. Microbiological quality was also determined in whole mushrooms before slicing.

\section{Gas composition $\left(\mathrm{CO}_{2}\right.$ and $\left.\mathrm{O}_{2}\right)$}

Carbon dioxide and oxygen levels were determined using an $\mathrm{O}_{2}$ and $\mathrm{CO}_{2}$ head space gas analyzer Checkmate model 9900 (PBI- Dansensor, Denmark). Samples were automatically taken with a syringe through a septum (Simón et al. 2005).

\section{Colour of mushrooms}

Colour was determined by measuring the $\mathrm{L}^{*}$ parameter (luminance) in the $\mathrm{L}^{*} \mathrm{a} * \mathrm{~b} *$ mode of CIE, since it was found to be well correlated with mush- room whiteness (Gormley 1975, Burton 1987). The measurement was taken using a HunterLab MiniScan XE colorimeter with an 8-mm diameter diaphragm calibrated with a white tile $(\mathrm{X}=81.1, \mathrm{Y}$ $=86.0$ and $Z=91.8$ ). The measurement conditions were illuminant $\mathrm{C}$ with an observation angle of $10^{\circ}$.

For each tray, ten different slices were measured in the stripe insertion area and on both sides. The mean was calculated for each tray.

\section{Weight loss}

Mushroom weight loss was measured in four trays for each batch with a Mettler balance model PJ3600 (Mettler, Toledo, Spain) with 2 decimals precission. Samples were taken on days 0, 6, 9 and 13 of storage. On days 6, 9 and 13, the differences with respect to initial weight were calculated and expressed as percentages of weight loss.

\section{Microbiological quality}

Twenty-five grams of mushrooms were aseptically weighed and homogenized in a Stomacher (IUL, Barcelona, Spain) for 2 min with $225 \mathrm{ml}$ of sterile peptone water (Oxoid, Basingstoke, UK). Further decimal dilutions were made with the same diluent. The total number of mesophilic microorganisms was determined on Plate Count Agar (PCA, Merck, Darmstadt, Germany) in accordance with the pour plate method; the plates were incubated at $30^{\circ} \mathrm{C}$ for $72 \mathrm{~h}$ (ICMSF 1978). Pseudomonas spp were determined on King's B medium (King et al. 1954) with an incubation temperature of $25^{\circ} \mathrm{C}$ for 48 h. Enterobacteriaceae were determined on Violet Red Bile Glucose Agar (Difco, Detroit, MI), the plates were incubated at $37^{\circ} \mathrm{C}$ for 18 to $24 \mathrm{~h}$ (ICMSF 1978). Aerobic spore formers were determined using PCA in accordance with the pour plate method at $30^{\circ} \mathrm{C}$ for $72 \mathrm{~h}$ after a heat treatment at $80^{\circ} \mathrm{C}$ for $10 \mathrm{~min}$ to destroy vegetative cells and activate the germination (ICMSF 1978). Anaerobic spore formers were determined following the same procedure as for aerobic spores but with in- 
Vol. 15 (2006): 414-422.

cubation under anaerobiosis. Petri dishes were placed in an anaerobic jar (Oxoid) with a gas generating kit (Oxoid) in order to produce an anaerobic environment (ICMSF 1978).

\section{Sensorial quality}

The samples were visually evaluated for slice deformation and for the presence of brown blotches. Both aspects were evaluated according to the following scale: none 1 , slight 2 , moderate 3 , severe 4 and extreme 5 . The presence of unpleasant odours inside the package was also observed.

\section{Statistical analysis}

The experimental design was a factorial experiment $(2 \times 2 \times 3)$ in which the factors were the type of film, the temperature and the time of storage with two repetitions. An analysis of variance was performed using the SYSTAT program for Windows, Statistics version 7.0 (Evanston, Illinois, 1992). The comparison of means was performed using the LSD method for $\mathrm{P} \leq 0.05$ (Dagnelie 1975). This analysis was not applied to weight losses since they were measured throughout storage in the same packages. In this case, the standard error was calculated.

\section{Results and discussion}

\section{Modified atmospheres}

The atmospheres generated with the perforated PVC film were hardly modified, being very similar to the composition of air atmosphere at 3 or $9^{\circ} \mathrm{C}$ (0-0.5\% $\mathrm{CO}_{2}$ and $20-21 \% \mathrm{O}_{2}$ ) (Fig. 1).

The atmosphere within the non-perforated packages for the two storage temperatures became highly modified in the first 24 hours of storage. Thereafter, no significant differences in $\mathrm{CO}_{2}$ and $\mathrm{O}_{2}$ levels were observed during the storage period.
At $3{ }^{\circ} \mathrm{C}$ the non-perforated PVC film generated $\mathrm{CO}_{2}$ and $\mathrm{O}_{2}$ concentrations of $3.4 \%$ and $8.1 \%$, respectively, inside the packages (Fig. 1). These atmospheres may be considered as appropriate, since a $\mathrm{CO}_{2}$ level of up to $5 \%$ is considered phytotoxic for mushrooms (López-Briones et al. 1992). Moreover, $\mathrm{O}_{2}$ levels below $2 \%$ might be related to anaerobic respiration in mushrooms (Beit-Halachmy and Mannheim 1992). However, at $9^{\circ} \mathrm{C}, \mathrm{CO}_{2}$ and $\mathrm{O}_{2}$ levels of $4.5 \%$ and $0.15 \%$, respectively, were reached. These $\mathrm{O}_{2}$ levels are extremely low if compared with those reported by López-Briones et al. (1993), when $500 \mathrm{~g}$ of whole mushrooms were packaged in the same type of film as in this study and stored at $10^{\circ} \mathrm{C}$. These authors observed higher $\mathrm{O}_{2}$ levels ( $12 \%$ compared with our result of $0.15 \%$ ). The lower $\mathrm{O}_{2}$ concentration obtained in the present study may be due to the effect of slicing on the increase of the respiration rate of mushrooms and consequently a higher atmosphere modification. Moreover, respiration can be anaerobic with a $0.15 \%$ of $\mathrm{O}_{2}$ concentration (Tano et al. 1999).

\section{Colour}

Temperature and storage time had significant effect $(\mathrm{P} \leq 0.001)$ on the $\mathrm{L}^{*}$ parameter. A decrease in the $\mathrm{L}^{*}$ parameter is related with mushroom browning. $L^{*}$ values decreased with the storage time and were lower when mushrooms were stored at $9^{\circ} \mathrm{C}$ than at $3^{\circ} \mathrm{C}$ (Fig. 2), although all values were above 80 , which is the acceptability limit considered by López-Briones et al. (1993).

Although film type had no significant effect on the $L^{*}$ parameter, a lower value of $L$ was observed in mushrooms packaged in non-perforated PVC stored at $9^{\circ} \mathrm{C}$ compared to those packaged in perforated $\mathrm{PVC}$ and stored at the same temperature. This fact could be explained by the atmosphere generated in the non-perforate PVC $\left(\mathrm{CO}_{2}\right.$ levels of $4.5 \%$ and $\mathrm{O}_{2}$ levels of $0.15 \%$ ) which could cause colour deterioration. These findings are in line with those reported by López-Briones et al. (1993), who reported higher external and internal color deterioration of whole mushrooms when $\mathrm{CO}_{2}$ concentration increased. 


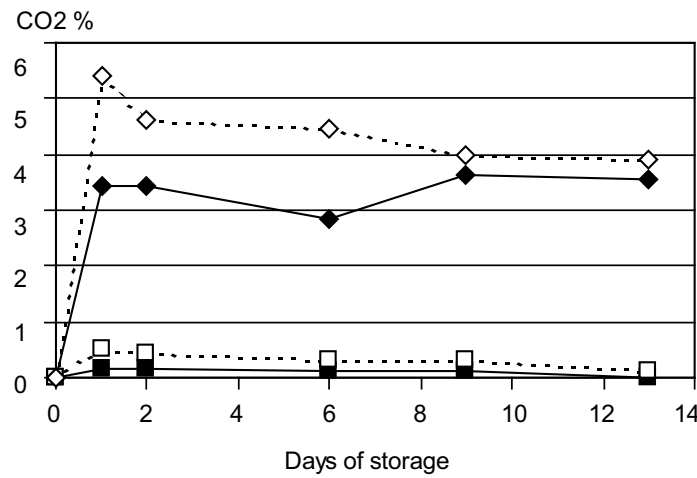

$\longrightarrow$ Perforated $3^{\circ} \mathrm{C}$

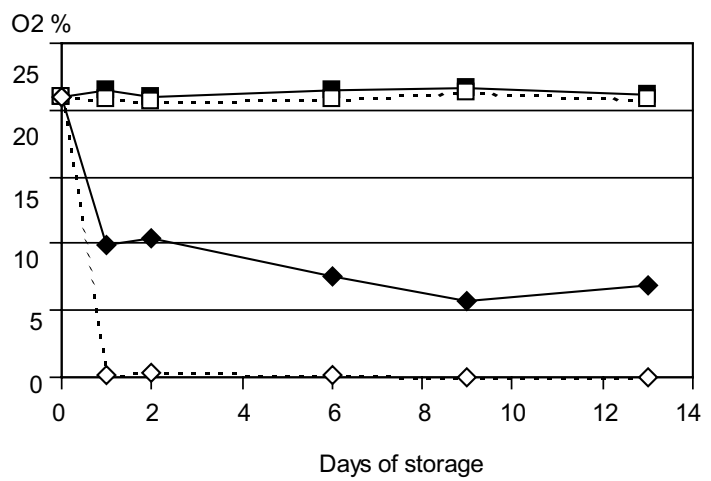

- - - - Perforated $9^{\circ} \mathrm{C} \quad \cdots \diamond-\cdot$ Non perforated $9^{\circ} \mathrm{C}$

Fig. 1. Oxygen and carbon dioxide concentrations in fresh sliced mushroom overwrapped with perforated and non-perforated PVC stored at two different temperatues $3^{\circ} \mathrm{C}$ and $9^{\circ} \mathrm{C}$. $\mathrm{LSD}_{0.05}=0.79$ for $\mathrm{CO}_{2} ; \mathrm{LSD}_{0.05}=2.97$ for $\mathrm{O}_{2}$.

\section{Weight loss}

The storage temperature exerted a strong influence on weight loss, the effect being twice at $9^{\circ} \mathrm{C}$ compared to that at $3^{\circ} \mathrm{C}$. Weight losses of 3.0-3.7\% and $5-6.3 \%$ were observed after 13 days of storage at $3^{\circ} \mathrm{C}$ and $9^{\circ} \mathrm{C}$, respectively (Table 1 ). These weight losses were revealed by the dehydrated appearance of the mushrooms in the latter case.

The difference in sliced mushroom weight losses between the packages overwrapped with the two types of films was very small, with a lower value in the case of the non-perforated PVC film (Table 1). This small difference found could be explained since the non-perforated PVC has a high water vapour transmission rate $\left(200 \mathrm{~g} \mathrm{~m}^{-2} \mathrm{day}^{-1} \mathrm{ac}-\right.$ cording to the manufacturer's data), which could prevent mushrooms dehydration without an excessive condensation inside the packages as it can be observed when less permeable to water vapour films are used (Simón et al. 2005).

\section{Microbiology}

Mesophile and Pseudomonas growth were very similar in sliced mushrooms, as shown in Figure 3. Pseudomonas initial counts in whole mushrooms
Luminance $L^{*}$

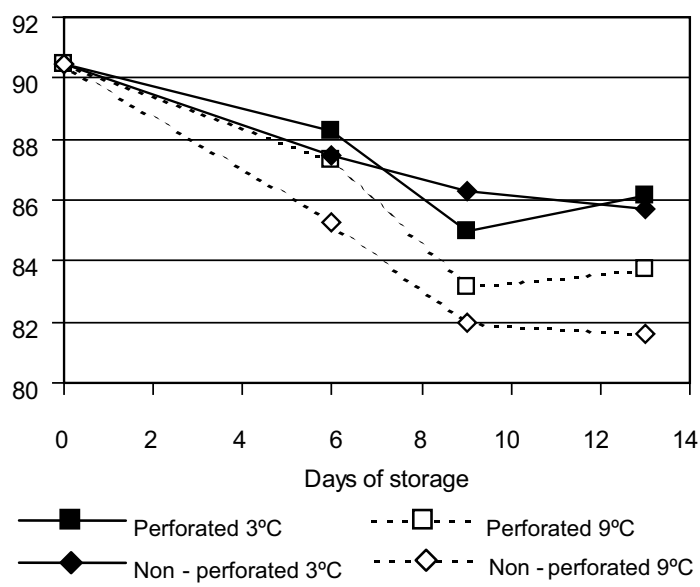

Fig. 2. Variation with time of Luminance $\left(\mathrm{L}^{*}\right)$ for fresh sliced mushrooms overwrapped with perforated and nonperforated PVC stored at two different temperatues $3^{\circ} \mathrm{C}$ and $9^{\circ} \mathrm{C} . \mathrm{LSD}_{0.05}=2.6$.

were $7.2 \log _{10} \mathrm{cfu} \mathrm{g}^{-1}$ while in sliced mushrooms were $7.8 \log _{10} \mathrm{cfu} \mathrm{g}^{-1}$. These data suggest that slicing may enhance microbial counts around $0.5 \log _{10}$ units. Brennan and Gormley (1998) reported initial Pseudomonas counts on sliced mushrooms of 6 $\log _{10} \mathrm{cfu} \mathrm{g}^{-1}$, whereas López-Briones et al. (1992) 
Vol. 15 (2006): 414-422.

Table 1. Weight losses (\%) in fresh sliced mushrooms packaged in perforated PVC and non perforated PVC stored at $3^{\circ} \mathrm{C}$ and $9^{\circ} \mathrm{C}$.

\begin{tabular}{lcccc}
\hline Days of storage & \multicolumn{4}{c}{ Treatment } \\
\cline { 2 - 5 } & $\begin{array}{c}\text { Perforated } \\
3^{\circ} \mathrm{C}\end{array}$ & $\begin{array}{c}\text { Non-perforated } \\
3^{\circ} \mathrm{C}\end{array}$ & $\begin{array}{c}\text { Perforated } \\
9^{\circ} \mathrm{C}\end{array}$ & $\begin{array}{c}\text { Non-perforated } \\
9^{\circ} \mathrm{C}\end{array}$ \\
\hline 6 & $1.83 \pm 0.02^{\mathrm{a}}$ & $1.38 \pm 0.04$ & $3.02 \pm 0.07$ & $2.32 \pm 0.10$ \\
9 & $2.61 \pm 0.04$ & $2.08 \pm 0.04$ & $4.55 \pm 0.10$ & $3.54 \pm 0.15$ \\
13 & $3.74 \pm 0.08$ & $3.06 \pm 0.05$ & $6.36 \pm 0.15$ & $5.00 \pm 0.22$ \\
\hline
\end{tabular}

a: means \pm standard error

$\mathrm{N}=4$

reported Pseudomonas counts of $5.5 \log _{10} \mathrm{cfu} \mathrm{g}^{-1}$ for whole mushrooms.

The film type and both the storage temperature and time had a significant influence $(\mathrm{P} \leq 0.001)$ on mesophile and Pseudomonas growth. After 13 days of storage, the mesophile and Pseudomonas counts in mushrooms were $0.8-0.93 \log _{10}$ units higher at $9^{\circ} \mathrm{C}$ than at $3^{\circ} \mathrm{C}$, for both perforated and non-perforated PVC films. After 9 days of storage, mesophile and Pseudomonas counts were lower in mushrooms packaged in non-perforated PVC compared to those packaged in perforated PVC at both temperatures (Figure 3). The lower counts observed at $3^{\circ} \mathrm{C}$ in mushrooms packaged in non-perforated PVC could be due to the $\mathrm{CO}_{2}$ levels of $3.4 \%$ generated within this film. By contrast, López-Briones et al. (1992) did not observe any reduction in mesophiles when mushrooms were stored in atmospheres with $2.5-5 \% \mathrm{CO}_{2}$ levels at $10^{\circ} \mathrm{C}$. These contradictory results could be explained by the fact that the inhibitory effect of $\mathrm{CO}_{2}$ is higher at low temperatures (Dixon and Kell 1989). The lower counts observed in mushrooms packaged in non-perforated PVC compared to those packaged in perforated $\mathrm{PVC}$ at $9^{\circ} \mathrm{C}$ could be explained by the low $\mathrm{O}_{2}$ level generated $(0.15 \%)$, which may affect the growth of aerobic microorganisms.

The film type and both the storage temperature and time had a significant influence $(\mathrm{P} \leq 0.001)$ on the growth of Enterobacteriaceae, particularly the storage temperature (Figure 3 ). At $9^{\circ} \mathrm{C}$, however, high Enterobacteriaceae counts were recorded on day 13 (6.5-7 $\left.\log _{10} \mathrm{cfu} \mathrm{g}^{-1}\right)$. Enterobacteriaceae growth may be prevented by storage at low temperature (Adams and Moss 2000). At $9^{\circ} \mathrm{C}$, Enterobacteriaceae counts of mushrooms were $0.5 \log _{10}$ units lower with perforated PVC than with non-perforated PVC. Facultative anaerobes such as Enterobacteriaceae are less affected by low $\mathrm{O}_{2}$ levels than other microorganisms such as Pseudomonas, and compete better with other types of bacteria in the presence of low oxygen concentrations (Adams and Moss 2000). This fact highlights the importance of a continuous cold chain for the microbiological quality of packaged fresh sliced mushrooms.

The film type and both the storage temperature and time exerted a significant influence $(\mathrm{P} \leq 0.001)$ on aerobic spore formers. After 13 days of storage, these counts were 4.9 and $3.7 \log _{10} \mathrm{cfu} \mathrm{g}^{-1}$ at $3^{\circ} \mathrm{C}$ and 6.1 and $4.3 \log _{10} \mathrm{cfu} \mathrm{g}^{-1}$ at $9^{\circ} \mathrm{C}$, respectively, in perforated and non-perforated PVC (Figure 3). Lower aerobic spore formers were observed in mushrooms packaged in non-perforated PVC, and particularly after 13 days of storage. The inhibitory effect of non-perforated PVC could be attributed to the high $\mathrm{CO}_{2}$ level reached at $3^{\circ} \mathrm{C}$ and the low $\mathrm{O}_{2}$ level reached at $9^{\circ} \mathrm{C}$.

Anaerobic spore formers were only detected in mushrooms packaged in non-perforated $\mathrm{PVC}$ at $9^{\circ} \mathrm{C}$, reaching 1.9 and $3.4 \log _{10}$ cfu g $^{-1}$ after 6 and 13 days of storage, respectively (Table 2). This fact could be attributed to the low $\mathrm{O}_{2}$ levels generated within the packages. Some authors have suggested a potential anaerobic pathogen growth under these conditions (Beit-Halachmy et al. 1992). Sugiyama and Yang (1975) detected botulinal toxin production in mushrooms inoculated with $5 \times$ 
González-Fandos, E. et al. Packaged fresh sliced mushrooms
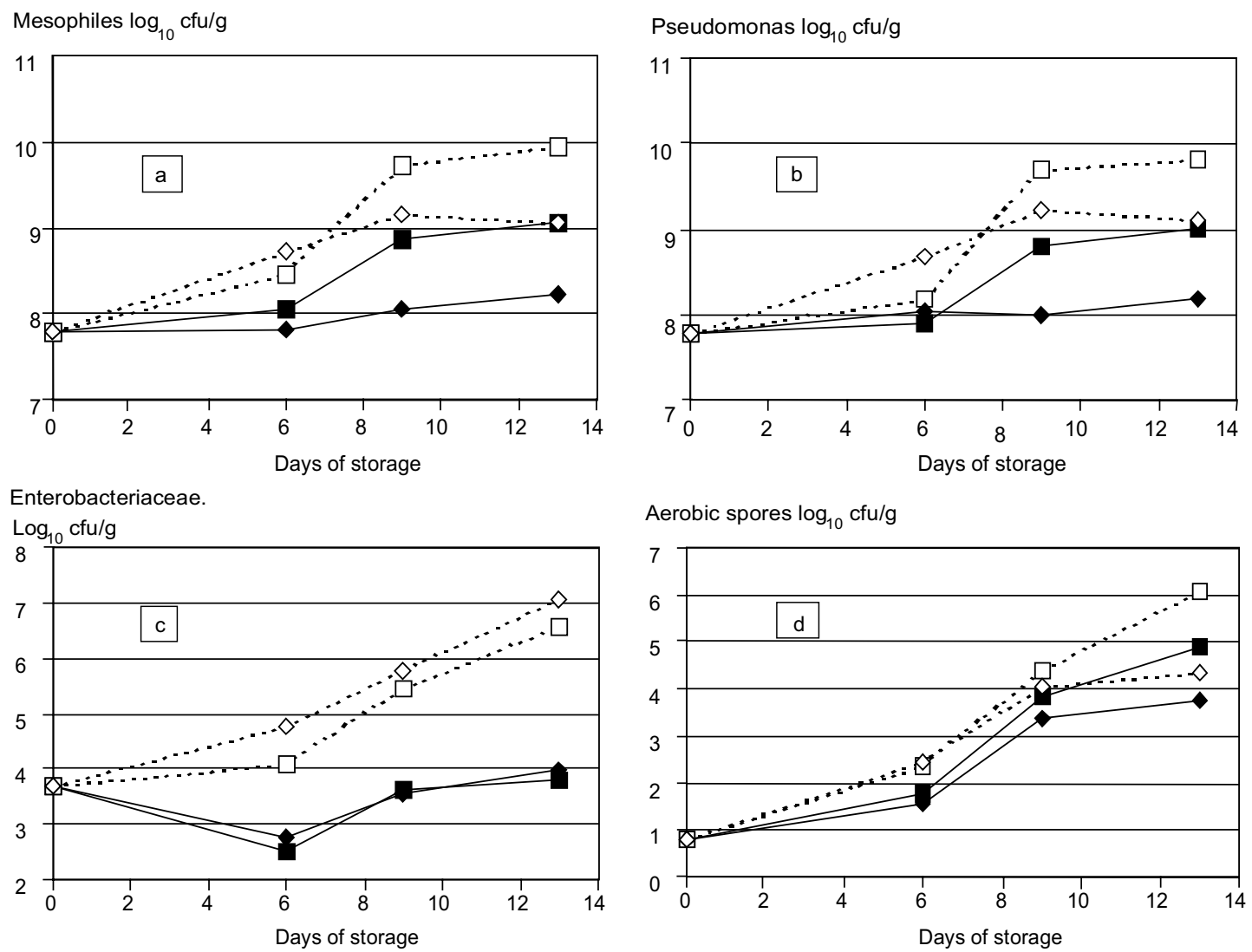

Aerobic spores $\log _{10} \mathrm{cfu} / \mathrm{g}$

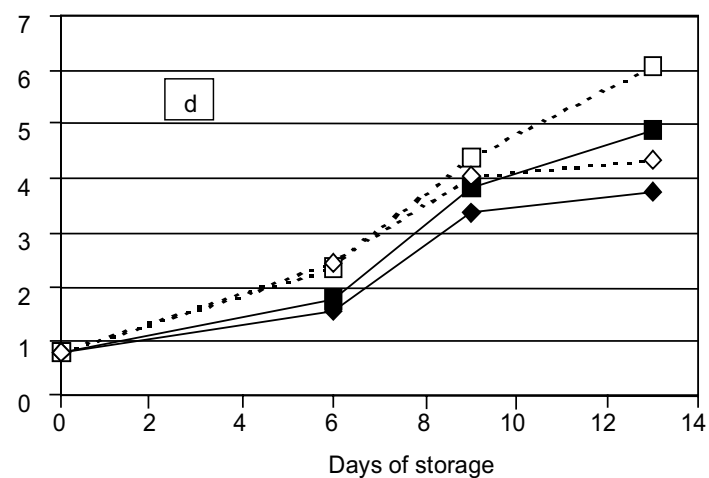

$\longrightarrow$ Perforated $3^{\circ} \mathrm{C} \longrightarrow$ Non - perforated $3^{\circ} \mathrm{C}$

- - - - - Perforated $9^{\circ} \mathrm{C} \quad-\cdot \diamond-\cdot$ Non-perforated

Fig. 3. Changes in the microbial population of fresh sliced mushrooms overwrapped with perforated and non-perforated PVC stored at two different temperatues $3^{\circ} \mathrm{C}$ and $9^{\circ} \mathrm{C}$. LSDs for $\mathrm{P} \leq 0.05: \mathbf{a}=0.28 ; \mathbf{b}=0.36 ; \mathbf{c}=0.25$ and $\mathbf{d}=0.34$.

$10^{3} \mathrm{cfu} \mathrm{g}^{-1}$ of $C$. botulinum type A, packaged in non-perforated $\mathrm{PVC}$ at $20^{\circ} \mathrm{C}$, in which $\mathrm{O}_{2}$ levels below $2 \%$ were reached. On other hand, Notermans et al. (1989) found anaerobic spore formers counts between 2.7 and $3.7 \log _{10}$ cfu g $^{-1}$ in mushrooms collected from production farms. These authors found C. botulinum in the casing soil but not in the mushrooms. They assumed that the ratio number of anaerobic spore formers to number of C. botulinum in mushrooms was the same as that detected in the casing soil, and thus these authors estimated that the incidence of $C$. botulinum in mushrooms was between $<0.08$ to 0.16 organisms per $100 \mathrm{~g}$ of product. The levels of C. botulinum in mushrooms estimated by Notermans et al. (1989) were lower than those inoculated by Sugiyama and Yang (1975) and detectable botulinal toxin was not produced unless large numbers of $C$. botulinum spores were inoculated into mushrooms (Sugiyama and Yang 1975).

Nevertheless, atmospheres which promote the anaerobic spore formers growth must be avoided, and this is obtained at $3{ }^{\circ} \mathrm{C}$ in the present study.

\section{Sensorial quality}

When mushrooms were stored at $3^{\circ} \mathrm{C}$, the mushroom slices had a good appearance in both films (perforated and non-perforated PVC) after 9 days. 
Vol. 15 (2006): 414-422.

Table 2. Anaerobic spore formers $\left(\log _{10} \mathrm{cfu} \mathrm{g}^{-1}\right)$ of fresh sliced mushrooms packaged in perforated and non-perforated PVC films, stored at $3^{\circ} \mathrm{C}$ and $9^{\circ} \mathrm{C}$

\begin{tabular}{|c|c|c|c|c|}
\hline \multirow{2}{*}{ Treatment } & \multicolumn{4}{|c|}{ Days of storage } \\
\hline & 0 & 6 & 9 & 13 \\
\hline Perforated $3^{\circ} \mathrm{C}$ & nd & nd & nd & nd \\
\hline Non-perforated $3^{\circ} \mathrm{C}$ & nd & nd & nd & nd \\
\hline Perforated $9^{\circ} \mathrm{C}$ & nd & nd & nd & nd \\
\hline Non-perforated $9^{\circ} \mathrm{C}$ & nd & 1.92 & 2.38 & 3.35 \\
\hline
\end{tabular}

nd: not detected

However, a slight deformation in mushroom slices and a moderate incidence of brown blotches was observed with perforated PVC, while this was not evident with non-perforated PVC on day 13 (Table 3). This may be attributed to the lower Pseudomonas counts observed with non-perforated PVC, since this bacterial genus is considered responsible for bacterial blotch (Beelman et al. 1989, Soler-Rivas et al. 1999, Wong and Preece 1982).

Severe slice deformation and the incidence of brown blotches, possibly of bacterial origin, were observed when mushrooms were packaged in perforated PVC and stored at $9^{\circ} \mathrm{C}$. In contrast, the mushrooms packaged in non-perforated PVC and stored at the same temperature had a better appearance with practically no deformation or blotches (Table 3). This may be attributed to the fact that the anoxia atmosphere formed in the package inhibited mushroom development and Pseudomonas growth. But under these conditions off-odours due to anaerobic respiration were detected, with a possible accumulation of ethanol and acetaldehyde (Tano et al. 1999). For this reason, and also due to the growth of anaerobic spore formers found in the present study, these mushrooms must be considered as inadequate for consumption despite their acceptable appearance.

\section{Conclusions}

Storage temperature was the most important factor for maintaining the quality and extending the shelf
Table 3. Sensory evaluation of fresh sliced mushrooms packaged in perforated $\mathrm{PVC}$ and non perforated PVC stored at $3^{\circ} \mathrm{C}$ and $9^{\circ} \mathrm{C}$.

\begin{tabular}{lcccc}
\hline $\begin{array}{l}\text { Days of } \\
\text { storage }\end{array}$ & \multicolumn{4}{c}{ Treatment } \\
\cline { 2 - 5 } & $\begin{array}{c}\text { Perforated } \\
3^{\circ} \mathrm{C}\end{array}$ & $\begin{array}{c}\text { Non- } \\
\text { perforated } \\
3^{\circ} \mathrm{C}\end{array}$ & $\begin{array}{c}\text { Perforated } \\
9^{\circ} \mathrm{C}\end{array}$ & $\begin{array}{c}\text { Non- } \\
\text { perforated } \\
9^{\circ} \mathrm{C}\end{array}$ \\
\hline \multicolumn{5}{c}{ Slice deformation * } \\
6 & 1 & 1 & 3 & 1.5 \\
9 & 1 & 1 & 4.5 & 1 \\
13 & 2 & 1 & 5 & 1 \\
Brown blotches incidence $*$ & & \\
6 & 1 & 2 & 1 & 1.5 \\
9 & 1 & 1 & 4 & 1 \\
13 & 3 & 1.5 & 4.5 & 1.5 \\
\hline
\end{tabular}

* Score: 1:none; 2: slight; 3: moderate; 4: severe; 5 : extreme.

life of sliced mushrooms in both perforated and non-perforated PVC films. A storage temperature of $3^{\circ} \mathrm{C}$ was appropriate, whereas temperature of $9^{\circ} \mathrm{C}$ was excessive for the mushroom sliced packaged in both PVC films.

The gas composition generated with the perforated PVC film inside the package was similar to the composition of air atmosphere, regardless of storage temperature. Although mushroom quality was preserved for 9 days at $3^{\circ} \mathrm{C}$, when temperature was $9^{\circ} \mathrm{C}$ they deteriorated rapidly, mainly due to microbial growth. 
González-Fandos, E. et al. Packaged fresh sliced mushrooms

The atmosphere generated with non-perforated PVC was adequate to inhibit microbial growth at $3^{\circ} \mathrm{C}$. Under these conditions, shelf life was approximately 13 days. However, the atmosphere generated at $9^{\circ} \mathrm{C}$ had an extremely low $\mathrm{O}_{2}$ content, which caused off-odours and promoted the growth of anaerobic spore formers, although the appearance of sliced mushrooms was acceptable.

Acknowledgements. The authors thank the Regional Government of La Rioja (Spain) for its financial support.

\section{References}

Adams, M.R. \& Moss, M.O. 2000. Food microbiology. 2nd ed. Cambridge: Royal Society of Chemistry. 479 p.

Beelman, R.B., Guthrie, B.D. \& Royse, D.J. 1989. Influence of bacterial populations on postharvest deterioration of fresh mushrooms. In: Proceedings of the twelfth international congress on the science and cultivation of edible fungi. Braunschweig, Germany. p. 655-665.

Beit-Halachmy, I. \& Mannheim, C.H. 1992. Is modified atmosphere packaging beneficial for fresh mushrooms? Lebensmittel Wissenschaft und Technology 25: 426432.

Brennan, M.H. \& Gormley, T.R. 1998. Extending the shelf life of fresh sliced mushrooms. Research report no 2. The National Food Centre, Dunsinea, Castleknock, Dublin. 30 p.

Brennan, M., Le Port, G. \& Gormley, R. 2000. Post-harvest treatment with citric acid or hydrogen peroxide to extend the shelf life of fresh sliced mushrooms. Lebensmittel Wissenschaft und Technology 33: 285-289.

Burton, K.S., Frost, C.E. \& Nichols, R. 1987. A combination plastic permeable film system for controlling postharvest mushroom quality. Biotechnology Letters 9: 529534.

Dagnelie, P. 1975. La comparaison de $p$ moyennes deux à deux. In: Théorie et methodes statistiques. Applications agronomiques vol 2. Belgie: Les presses agronomiques de Gembloux. 242 p.

Dixon, N.M. \& Kell, P.B. 1989. The inhibition by $\mathrm{CO}_{2}$ of the growth and metabolism of microorganisms. Journal Applied Bacteriology 67: 109.

Gormley, T.R. 1975. Chill storage of mushrooms. Journal of the Science of Food and Agriculture 26: 401-411.

ICMSF 1978. Microorganisms in foods. 1: Their significance and methods of enumeration. 2nd ed. International Commission on Microbiological Specifications for Foods. Toronto: University of Toronto Press. 439 p.

Kader, A.A. 1986. Biochemical and physiological basis for effects of controlled and modified atmospheres on fruits and vegetables. Food Technology 40: 99-104.
King, E.O., Ward, M.K. \& Ranzy, E.D. 1954 Two simple media for the demostration of pyocyanin and fluorescein. Journal of Laboratory and Clinical Medicine 44: 301307.

López-Briones, G., Varoquaux, P., Chambroy, Y., Bouquant, J., Bureau, G. \& Pascat, B. 1992. Storage of common mushroom under controlled atmospheres. International Journal of Food Science and Technology 27: 493-505.

López-Briones, G., Varoquaux, P., Bureau, G. \& Pascat, B. 1993. Modified atmosphere packaging of common mushroom. International Journal of Food Science and Technology 28: 57-68.

Murr, D.P. \& Morris, L.L. 1975. Effect of storage atmosphere on postharvest growth of mushrooms. Journal American Society Horticultural Science 100: 298-301.

Nichols, R. 1985. Postharvest physiology and storage. In: Flegg, P.B. et al. (eds.). The biology and technology of the cultivated mushroom. England. p. 196-210.

Notermans, S., Dufrenne, J. \& Gerrits, J.P.G. 1989. Natural occurrence of Clostridium botulinum on fresh mushrooms (Agaricus bisporus). Journal of food Protection 52: 733-736.

Roy, S., Anantheswaran, R.C. \& Beelman, R.B. 1995. Fresh mushroom quality as affected by modified atmosphere packaging. Journal of Food Science 60: 334-340.

Simón, A. 2001. Manejo postrecolección del champiñón (Agaricus bisporus L.) para su comercialización en fresco. In: Actas de las III Jornadas Técnicas del champiñón y otros hongos comestibles en Castilla-la Mancha. Iniesta, Cuenca, Spain. p. 289-300.

Simón, A., González-Fandos, E. \& Tobar, V. 2005. The sensory and microbiological quality of fresh sliced mushroom (Agaricus bisporus L.) packaged in modified atmospheres. International Journal of Food Science and Technology 40: 943 -952.

Soler-Rivas, C., Arpin, N., Olivier, J.M. \& Wichers, H.J. 1999. WLIP, a lipodepsipeptide of Pseudomonas "reactans", as inhibitor of the brown blotch disease of Agaricus bisporus. Journal of Applied Microbiology 86: 635641.

Sugiyama, H. \& Yang, K.H. 1975. Growth potential of Clostridium botulinum in fresh mushrooms packaged in semipermeable plastic film. Applied Microbiology 30: 964-969.

Suslow, T.V. \& Cantwell, M. 1999. Mushroom: Recommendations for maintaining postharvest quality. Updated Nov 2006. Cited Nov 2006. Available on the Internet: http://postharvest.ucdavis.edu/producefacts/vegetables/mushroom

Tano, K., Arul, J., Doyon, G. \& Castaigne, F. 1999. Atmospheric composition and quality of fresh mushrooms in modified atmosphere packages as affected by storage temperature abuse. Journal of Food Science 64: 10731077.

Wong, W.C. \& Preece, T.F. 1982. Pseudomonas tolaasii in cultivated mushrooms (Agaricus bisporus) crops: numbers of the bacterium and symptom development on mushrooms grown in various environments after artificial inoculation. Journal of Applied Bacteriology 53: 87-96.

Zagory, D. \& Kader, A. 1988. Modified atmosphere packaging of fresh produce. Food Technology 42: 70-77. 